\title{
No escape: most insect colonisers of an introduced fig tree in Cyprus come from the plant's native range
}

\author{
S. G. Compton $\mathbb{D} \cdot$ M. Stavrinides $\cdot$ C. Kaponas $\cdot$ P. J. Thomas
}

Received: 20 July 2019/ Accepted: 8 November 2019/Published online: 18 November 2019

(C) The Author(s) 2019

\begin{abstract}
Plants that become invasive outside their native range often benefit from the absence of their native-range herbivores. Ficus microcarpa is a widely-planted Asian-Australasian species of fig tree that has become invasive in parts of its introduced range. As in most places where it is planted, the pollinator of $F$. microcarpa has been introduced to Cyprus, together with at least six other Asian fig wasp species. We recorded the other insects feeding on the leaves, buds and stems of this fig tree in southern Cyprus. Eight sap-sucking insects were recorded, and one leaf-galling species, with some present at high frequencies and densities. The insects were a mix of introduced polyphagous species and introduced $F$. microcarpa specialists. They included the first European record of the fig leaf galling psyllid Trioza brevigenae, which was described from India. Ficus microcarpa has not escaped from its native-range phytophages, but they appear to be free of their own specialist parasitoids and predators. The result is a herbivore load than may be comparable with what the plant experiences in its countries of origin. This is
\end{abstract}

S. G. Compton $(\bowtie) \cdot$ P. J. Thomas

School of Biology, University of Leeds, Leeds LS2 9JT, UK

e-mail: s.g.a.compton@leeds.ac.uk

M. Stavrinides · C. Kaponas

Department of Agricultural Sciences, Cyprus University

of Technology, Arch. Kyprianos 30, 3036 Limassol,

Cyprus likely to reduce the invasiveness of $F$. microcarpa, but at the same time makes the plant a less attractive option for future planting.

Keywords Biological control - Ficus microcarpa . Street trees · Trophic cascades

\section{Introduction}

Natural terrestrial tritrophic communities typically comprise plants, the animals that eat them, and predators and parasitoids of the plant feeders. The structure of such naturally evolved communities is not replicated when organisms are transported outside their natural range, with inevitable consequences for their population dynamics. In particular, the presence or absence of animals feeding at higher trophic levels has cascading effects among species at lower levels (Price et al. 1980; López-Núñez et al. 2017). Current unprecedented rates of international transport and trade are leading to more frequent anthropogenic movement of plants and animals around the planet and facilitating the establishment of non-native species. A proportion of these become invasive and generate significant economic and ecological damage (Pimentel et al. 2005). Although introduced plants can be colonised by native insects, especially if the plant has closely-related species in the area, their impact on 
the plant is often less than it would have experienced in its native range, at least initially (Schilthuizen et al. 2016). This lack of specialist phytophagous associates is one reason that some plants become more abundant in their introduced than their native ranges (the 'enemy release hypothesis', Keane and Crawley 2002). Introduced plant-feeding insects can achieve higher densities than in their native ranges for the same reason, because their own specialist predators and parasitoids are absent. Classical biological control of weeds is based on the deliberate transport of natural enemies from a plant's natural range into areas where the plant has been introduced (McFadyen 1998), but un-sanctioned 'accidental' transport of phytophagous insects can achieve similar results. One example is provided by an apionid weevil that was introduced, apparently accidentally, into South Africa. The weevil has contributed greatly to the control of this invasive species, especially when it is present in combination with deliberately introduced agents (Hoffmann and Moran 1998). Invasive insects may be harmful if they damage beneficial plant species, but they could also have positive implications if they damage invasive plant species in the same way that a deliberately introduced biological control agent would.

An increasing number of exotic fig tree species (Ficus, Moraceae) are planted in gardens and public spaces. In addition to being hardy and visually attractive, they have the advantage that they normally fail to set seed. This is because of their unique pollination system, where each of the hundreds of species of fig trees is dependent on one or a small number of host specific fig wasp species (Agaonidae) for pollination. In a few fig tree species this advantage has been lost, because the trees' specific pollinators have been transported between continents. The most widely distributed, and now almost ubiquitous, pollinator (Eupristina verticillata Waterston) is associated with $F$. microcarpa L., a species native to Asia and Australasia (Wang et al. 2015a). This fig tree is widely-planted in gardens and streets across the Mediterranean and in sub-tropical and tropical areas around the world. Pollinated F. microcarpa become less attractive as street trees, because fallen ripe figs are unsightly. Pollinated figs are also popular with native and introduced birds, which disperse their seeds. This results in seedling establishment on walls and buildings, where they can eventually cause damage. Expansion into natural habitats is rare so far in Mediterranean Europe, but $F$. microcarpa is relatively salt tolerant and has become invasive on the islands of Hawaii and Bermuda, where it threatens the remaining fragments of semi-natural vegetation (Wang et al. 2015a).

Ficus microcarpa has been planted extensively along roads in municipal areas across the Eastern Mediterranean island of Cyprus. In its native range, Ficus microcarpa supports a diverse community of host specific fig wasps that includes its pollinators together with ovule-galling species and parasitoids. An increasing number of these species have been introduced to Cyprus and other areas around the Mediterranean and the species richness of Mediterranean fig wasp communities on individual trees can now be as high as on trees in their native range, but parasitoids are rare or absent (Wang et al. 2015a, b). Some of these fig wasps can prevent seed production in the figs they inhabit, but despite the frequent absence of their parasitoids they are currently having limited impact on the reproductive success of their hosts. All the fig wasps are largely or entirely restricted to $F$. microcarpa, and must have been introduced from the native range of the plant, even though several have never been recorded from their host's native range. Insects feeding on vegetative tissues are often not as host specific, and they may include local species that have extended their host ranges to include fig trees as hosts.

Here we describe the broader insect community feeding on planted F. microcarpa in an area of Cyprus. The questions we addressed were: which insect species are feeding on the leaves, buds and stems of F. microcarpa? How abundant are they? And what are their origins?

\section{Methods}

Limassol (Lemesós) is a city on the southern coast of the island of Cyprus in the eastern Mediterranean. Ficus microcarpa is planted widely within the city along coastal roads and in car parks, communal parks and urban squares. Self-seeded small plants are present on buildings and pavements. The size of the largest trees suggest that planting started at least several decades ago. The street-planted $F$. microcarpa are usually subject to frequent heavy pruning that eliminates many of the insects feeding on the plant. In 
early summer 2018 we selected 50 individuals across a distance of $6.5 \mathrm{~km}$ from East-West across Limassol that had not been heavily pruned. The trees were chosen to represent the range of locations where the trees had been planted. None were more than about $1.5 \mathrm{~km}$ from the coast.

Visual inspection revealed that most inhabitants on the trees were located in leafy areas towards the periphery of the branches. Records of the insects present on the trees were obtained by sampling the terminal $30 \mathrm{~cm}$ of five branches per tree using a pruning pole. The number of leaves on the detached branches and the insect species present were recorded based on naked-eye observations, with later confirmation of identities using a binocular microscope when required. Sub-samples of 4 leaves per stem were examined for the presence of galls generated by the wasp Josephiella microcarpae Beardsley and Rasplus. F. microcarpa responds to the galling by premature leaf fall (Bhandari and Cheng 2016). Fallen leaves below each tree were scored for the number exit holes produced by emerging $J$. microcarpae adults.

\section{Results}

Nine insect species were feeding on the leaves and shoots of F. microcarpa, one of which was a new record for Cyprus, and another the first record for Europe (Table 1). All 50 trees had insects feeding on them, with up to six species present on a single tree (Fig. 1), but there was a noticeable absence of leaf chewing species. The leaf galling wasp J. microcarpae was the most widespread insect species (Fig. 2), with 48 of the 50 trees having its blister-like leaf galls present on at least one of the five sampled branches. It was also the species present on the highest proportion of the sampled branches (Fig. 3) and of the 250 leafy stems examined, $174(69.6 \%)$ had its galls present on the leaves. Described from specimens collected in

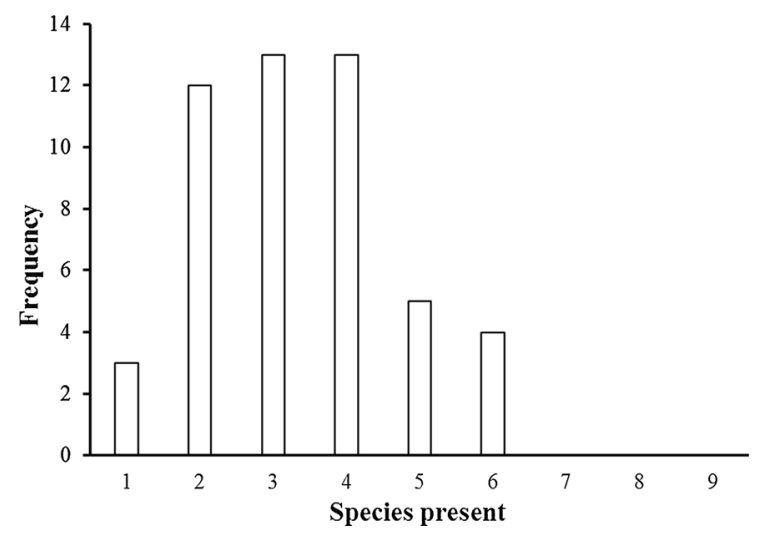

Fig. 1 The numbers of stem and leaf feeding insects present on individual $F$. microcarpa in Limassol

Table 1 Leaf and stem feeding insects recorded on Ficus microcarpa in Limassol, Cyprus, in 2018

\begin{tabular}{|c|c|c|c|c|}
\hline Order/family & Species & Origins & Locations and damage & Host range \\
\hline \multicolumn{5}{|l|}{ Homoptera } \\
\hline Homotomidae & $\begin{array}{l}\text { Macrohomotoma gladiata } \\
\text { Kuwayama }\end{array}$ & East Asia & $\begin{array}{l}\text { Loosely rolled leaves and } \\
\text { young leaf buds }\end{array}$ & $\begin{array}{l}\text { F. microcarpa. } \\
\text { Possibly other Ficus }\end{array}$ \\
\hline Triozidae & Trioza brevigenae Mathur & India & Rolled leaf galls & F. microcarpa \\
\hline Aleyrodidae & Singhiella simplex (Singh) & South-East Asia & Leaves & Ficus spp. \\
\hline Coccidae & Saissetia oleae (Olivier) & South Africa & Leaves and stems & Polyphagous \\
\hline Coccidae & Coccus hesperidum L. & Unclear & Leaves and stems & Polyphagous \\
\hline Coccidae & Ceroplastes rusci (L.) & Africa & Leaves and stems & Ficus and Citrus spp. \\
\hline Monophlebidae & $\begin{array}{l}\text { Icerya seychellarum } \\
\text { (Westwood) }\end{array}$ & $\begin{array}{l}\text { Possibly Southern } \\
\text { African }\end{array}$ & Leaves & Polyphagous \\
\hline \multicolumn{5}{|l|}{ Thysanoptera } \\
\hline Phlaeothripidae & $\begin{array}{l}\text { Gynaikothrips ficorum } \\
\text { (Marchal) }\end{array}$ & Asia & Folded leaf galls & Mainly F. microcarpa \\
\hline \multicolumn{5}{|l|}{ Hymenoptera } \\
\hline Pteromalidae & $\begin{array}{r}\text { Josephiella microcarpae } \\
\text { Beardsley and Rasplus }\end{array}$ & $\begin{array}{l}\text { Asia (but unknown from } \\
\text { native range) }\end{array}$ & Small rounded leaf galls & F. microcarpa \\
\hline
\end{tabular}




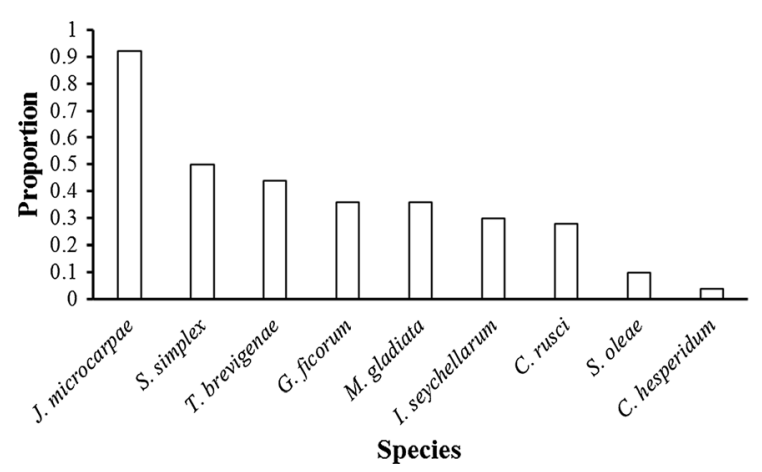

Fig. 2 The proportion of F. microcarpa in Limassol supporting each species of insect ( $\mathrm{n}=50$ trees)

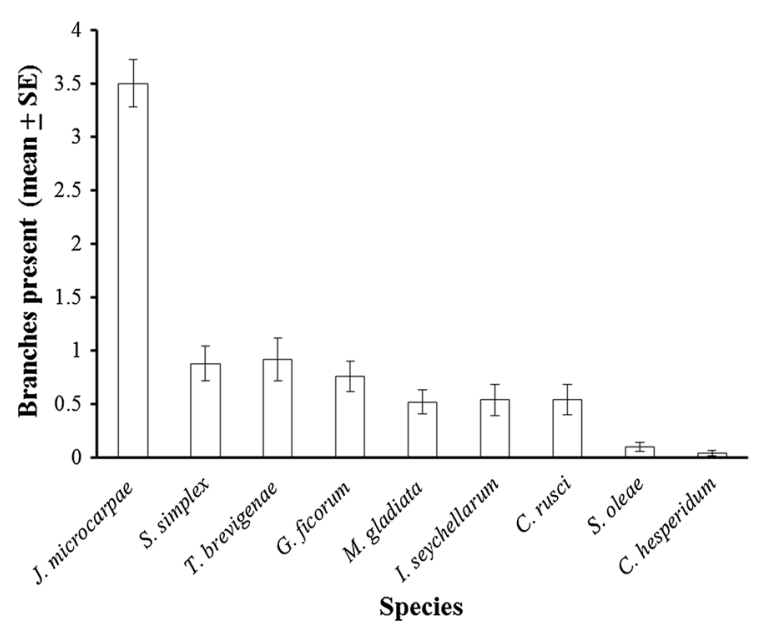

Fig. 3 The numbers of branches on each $F$. microcarpa that supported each insects (five branches sampled per tree)

Hawaii, California and the Canary Islands (Beardsley and Rasplus 2001), Josephiella microcarpae is an 'unknown follower' (sensu Farache et al. 2018), that has never been recorded from the native range of $F$. microcarpa, its only known host plant. It is now probably present wherever $F$. microcarpa is grown around the Mediterranean, and confirmed in Italy (Longo 2014) and Malta (Misfud et al. 2012).

From the five-stem samples from each tree, a mean of 3.48 ( $\mathrm{SD}=1.55)$ stems had one or more leaves galled by $J$. microcarpae. The terminal sections of these leafy stems had a mean of 25.61 leaves each ( $\mathrm{SD}=10.91, \mathrm{n}=250$ stems). $69.7 \%$ of the twenty randomly-selected leaves from each tree had at least one $J$. microcarpae gall present, with up to 22 galls present on a single leaf. The galls often coalesced and counts of the numbers of emergence holes produced

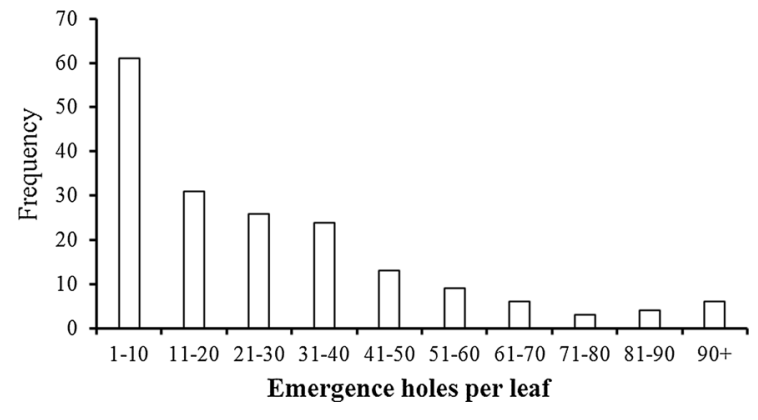

Fig. 4 The numbers of Josephiella microcarpae emergence holes present on fallen leaves of $F$. microcarpa where galls were present

by the females give a better idea of the numbers of wasps developing inside each leaf. A 1000 fallen leaf sample from the 50 trees (including leaves with no galls), recorded a mean of $16.28(\mathrm{SD}=22.25)$ emergence holes pre leaf. This may be an overestimate of the average number of wasps emerging from the leaves on the trees, because heavily galled leaves can be shed prematurely (Bhandari and Cheng 2016). On leaves where galls were present, up to 100 emergence holes were present (Fig. 4).

The remaining eight species recorded feeding on $F$. microcarpa in Limassol were all sucking insects (Table 1), with the whitefly Singhiella simplex the most abundant of the six species of sap-sucking hemipterans (Figs. 2, 3). This originally Asian species is known to feed on a range of Ficus species (Avery et al. 2011) and was reported previously from Cyprus (Ko et al. 2015). Its feeding causes yellowing of the leaves and defoliation. Feeding by the psyllid Trioza brevigenae results in characteristic longitudinal leaf rolls. Its host species was not recorded in the original description, but it was collected from an area of India within the native range of $F$. microcarpa, and it has not been recorded subsequently from any other Ficus species (Mathur 1973). This is a first record for Europe. The rolling of the leaves is stimulated by the sedentary early instars located on the underside of the leaves. The leaf-rolling they have generated then provides a refuge for later instars and adults, as well as other insects.

The less frequently recorded species feeding on $F$. microcarpa included three nearly cosmopolitan coccid scale insects (Table 1, Fig. 2). All three are polyphagous, although fig trees are particularly common hosts of the wax scale Ceroplastes rusci (Deng et al. 
2014). Icerya seychellarum is a significant pest of citrus crops that was first recorded from Europe (France) in 2006 (EPPOGlobalDatabase, accessed 2019). This is a new record for Cyprus, but it was already known from the eastern Mediterranean (Egypt) (EPPOGlobalDatabase, accessed 2019) and it has been recorded before on Ficus species (https:// www.cabi.org/isc/datasheet/28434). The characteristic white woolly residue and damage to buds and young leaves caused by Macrohomotoma gladiata was often prominent on the trees. The first European records of this species were from the Balearic Islands in 2009, and it quickly became widespread around the Mediterranean (Mifsud and Porcelli 2012). It has only been recorded from Ficus hosts (Bella and Rapisarda 2014) and has now spread to North America (Rung 2016). The thrips Gynaikothrips ficorum has mainly but not exclusively been reported from $F$. microcarpa. It is again widespread around the Mediterranean (https://www.cabi.org/isc/datasheet/26258) and has also been introduced into North and South America (Curis et al. 2015). Feeding by this species causes the leaves to fold vertically along the midrib (Rung 2016) in the same way that the well-known Gynaikothrips uzeli (Zimmermann) galls leaves of $F$. benjamina $\mathrm{L}$.

\section{Discussion}

Ficus microcarpa growing in Cyprus supports a diverse phytophagous insect fauna that is composed of a mixture of almost cosmopolitan polyphages and species that feed only or mainly on this plant. Colonisation of $F$. microcarpa by local native species appears to be absent, and the fauna is strongly biased towards phloem-feeding species, with a noticeable absence of leaf-chewing insects. The specialist Ficusfeeders have been transported from the native range of the plant in Asia, whereas the polyphagous species have various, less well defined origins. The fig wasp fauna on individual trees in Cyprus is now similar to that experienced by most trees in its native range (Wang et al. 2015a). Whether the number of leaf-, stem- and bud- feeding species on individual $F$. microcarpa trees is now approaching that on individual trees in its native range is unknown, but like the fig wasps the composition appears to be different, with a bias towards sap-sucking species. The size of the insect fauna in Cyprus is likely to increase further in the future because, for example, we detected only three of the six phytophages recorded feeding on $F$. microcarpa in Malta (Misfud et al. 2012) and there may be the potential for dispersal between the islands.

The extent of the native-range distributions of the monophagous and oligophagous species that have arrived in Cyprus is unknown, and the leaf-galler $J$. microcarpae, which is the most abundant species on the trees, has never been found within its putative native range. With a natural distribution that extends from India to Australia, phytophagous insect faunas associated with $F$. microcarpa in different regions will have evolved in isolation, separated by effective barriers to dispersal. Inter-continental transport and ineffective quarantine arrangements have brought together the more successful colonists to the Mediterranean and although the precise composition of the $F$. microcarpa fauna may vary from place to place, the size of the fauna on Cyprus is likely to be typical of the current situation in the Mediterranean as a whole (Misfud et al. 2012). No comparable data are available for the diversity and abundance of insects feeding on F. microcarpa in its native range, but casual observations of hundreds of street trees during fig wasp surveys through southern China, Thailand and Malaysia (SG Compton, unpublished) have never noticed the abundance of phytophages and the high levels of damage present on some individuals of this species in Cyprus. The insects may be able to reach such high densities in Cyprus because of a lack their own specialist predators and parasitoids (for example see Ko et al. 2015).

There are positive and negative consequences of the arrival of the insects feeding on Ficus microcarpa in Cyprus. It is now less attractive and more expensive to maintain, but the likely negative impact of the insects on their host plant's seed production should mean that seedling damage to buildings will be less frequent than would otherwise be the case (Caughlin et al. 2012), and also that the chance that this species may become naturalised, as has occurred in Malta, will be reduced. Given that many other Ficus species are available to growers, and that these species (currently) lack the pest problems associated with $F$. microcarpa, the long-term consequences will be that new plantings of street trees are likely to avoid using this species. Globally, the un-planned spread of insects that feed on F. microcarpa is likely to continue. Apparently monophagous species such as J. microcarpae are also 
potential candidates for biological control on islands such as Bermuda, where their host tree threatens the remaining pockets of natural vegetation.

Acknowledgements Identification of Icerya seychellarum was kindly confirmed by C. Malhumphy (Fera, York, UK). I.D. Hodkinson (Liverpool John Moores University, UK) assisted with identification of Trioza brevigenae galls. We also thank two anonymous referees for their helpful comments.

\section{Compliance with ethical standards}

Conflict of interest The authors declare that they have no conflict of interest.

Open Access This article is distributed under the terms of the Creative Commons Attribution 4.0 International License (http:// creativecommons.org/licenses/by/4.0/), which permits unrestricted use, distribution, and reproduction in any medium, provided you give appropriate credit to the original author(s) and the source, provide a link to the Creative Commons license, and indicate if changes were made.

\section{References}

Avery P, Mannion C, Powell C, McKenzie C, Osborne L (2011) Natural enemies managing the invasion of the Fig Whitefly, Singhiella simplex (Hemiptera: Aleyrodidae), infesting a Ficus benjamina hedge. Fla Entomol 94:696-698

Beardsley JW, Rasplus J-Y (2001) A new species of Josephiella (Hymenoptera:Agaonidae) forming leaf galls on Ficus microcarpa L. (Moraceae). J Nat Hist 35:33-40

Bella S, Rapisarda C (2014) New findings in Italy of the recently introduced alien psyllid Macrohomotoma gladiata and additional distributional records of Acizzia jamatonica and Cacopsylla fulguralis (Hemiptera Psylloidea). Redia 97:151-155

Bhandari B, Cheng Z (2016) Trunk injection of systemic insecticides to control stem and leaf gall wasps, Josephiella species (Hymenoptera: Agaonidae), on Chinese Banyan (Rosales: Moraceae) in Hawaii. Fla Entomol 99:172-177

Caughlin T, Wheeler JH, Jankowski J, Lichstein JW (2012) Urbanized landscapes favored by fig-eating birds increase invasive but not native juvenile strangler fig abundance. Ecology 93:1571-1580

Curis MC, Zamar MI, Bertolaccini I, Kirtz ME (2015) First record of Gynaikothrips ficorum (Marchal) on Ficus microcarpa L. from the province of Santa $\mathrm{Fe}$ and Gynaikothrips uzeli (Zimmermann (Thysanoptera, Phlaeothripidae) on Ficus benjamina L. (Urticales: Moraceae) from the province of Jujuy, Argentina. Rev Soc Entomol Argent 74:85-88

Deng J, Wang X, Yu F, Zhou Q, Bernardo U, Zhang Y, Wu S (2014) Rapid diagnosis of the invasive wax scale, Ceroplastes rusci Linnaeus (Hemiptera: Coccoidea: Coccidae) using nested PCR. J Appl Entomol 139:314-319

Farache FHA, Pereira CB, Koschnitzke C, Barros LO, Souza EMC, Felício DT, Gatti F, Cardona W, Rasplus J-Y,
Pereira RAS (2018) The unknown followers: discovery of a new species of Sycobia Walker (Hymenoptera: Epichrysomallinae) associated with Ficus benjamina L. (Moraceae) in the Neotropical region. J Hymenopt Res 67:85-102

Hoffmann J, Moran VC (1998) The population dynamics of an introduced tree, Sesbania punicea, in South Africa, in response to long-term damage caused by different combinations of three species of biological control agents. Oecologia 114:343-348

Keane RM, Crawley MJ (2002) Exotic plant invasions and the enemy release hypothesis. TREE 17:164-170

Ko CC, Shih YT, Schmidt S, Polaszek A (2015) A new species of Encarsia (Hymenoptera, Aphelinidae) developing on ficus whitefly Singhiella simplex (Hemiptera, Aleyrodidae) in China and Taiwan. J Hymenopt Res 46:85-90

Longo S (2014) http://www.georgofili.info/contenuti/uninsetto-galligeno-delle-foglie-di-ficus-micro-carpa/1603

López-Núñez FA, Heleno RH, Ribeiro $\mathrm{S}$, Marchante $\mathrm{H}$, Marchante E (2017) Four-trophic level food webs reveal the cascading impacts of an invasive plant targeted for biocontrol. Ecology 98:782-793

Mathur RN (1973) Descriptions and records of some Indian Psyllidae (Homoptera). Indian For Rec 11:59-87

McFadyen REC (1998) Biological control of weeds. Ann Rev Entomol 43:369-393

Mifsud D, Porcelli F (2012) The psyllid Macrohomotoma gladiata Kuwayama, 1908 (Hemiptera: Psylloidea: Homotomidae): a Ficus pest recently introduced in the EPPO region. Bull OEPP/EPPO Bull 4:161-164

Misfud D, Falzon A, Malumphy C, de Lillo E (2012) On some arthropods associated with Ficus species (Moraceae) in the Maltese Islands. Bull Entomol Soc Malta 5:5-34

Pimentel D, Zuniga R, Morrison D (2005) Update on the environmental and economic costs associated with alien-invasive species in the United States. Ecol Econ 52:273-288

Price PW, Bouton CE, Gross P, McPheron BA, Thompson JN, Weis AE (1980) Interactions among three trophic levels: influence of plant on interactions between insect herbivores and natural enemies. Ann Rev Ecol Syst 11:41-65

Rung A (2016) A new pest of Ficus in California: Macrohomotoma gladiata Kuwayama, 1908 (Hemiptera: Psylloidea: Homotomidae), new to North America. Check List 12(3): $1-5$

Schilthuizen M, Santos Pimenta LP, Lammers Y et al (2016) Incorporation of an invasive plant into a native insect herbivore food web. PeerJ 4:e1954

Wang R, Aylwin R, Barwell L et al (2015a) The fig wasp followers and colonists of a widely introduced fig tree, Ficus microcarpa. Insect Conserv Divers 8:322-336

Wang R, Aylwin R, Cobb J, Craine L, Ghana S, Reyes-Betancort JA, Quinnell RJ, Compton SG (2015b) The impact of fig wasps (Chalcidoidea), new to the Mediterranean, on reproduction of an invasive fig tree Ficus microcarpa (Moraceae) and their potential for its biological control. Biol Control 81:21-30

Publisher's Note Springer Nature remains neutral with regard to jurisdictional claims in published maps and institutional affiliations. 